\title{
Independence of Judicial Power as a Foundation of Human Rights Judicial Function in Indonesia
}

\author{
Yustina Trihoni Nalesti Dewi, W. Riawan Tjandra, and Grant R. Niemann
}

\begin{abstract}
The amendments to the 1945 Constitution of the Republic of Indonesia resulted in fundamental changes being made to the structure, position and function of all state institutions including the judiciary. These amendments were designed to influence and foster the growth of new values including democratic freedoms, people's sovereignty, protection of human rights, checks and balances, transparency, participation, accountability, and the rule of law. Unfortunately the provision of a fair trial is still not ensured before the Human Rights Court in Indonesia, despite fair trial guarantee being enshrined in the 1945 Constitution. What is before the law and according to law in fact is not in accordance with before the court and according to the court. There are still weaknesses in the judicial system of human rights with the position located between the existence of the guarantees of judicial power independence set in textual - explicit in the constitution (normative-theoretical context) and the needs for the practice of human right courts through the decisions that protect human rights substantively (factual-applicative context) requires a re-conceptualization of the position and function of the human right court based on the philosophy on the independence of judicial power
\end{abstract}

Index Terms-Independence of judicial power and human rights.

\section{INTRODUCTION}

Judicial independence is generally characterized by competence, independence, and impartiality and is fundamental for the provision of a fair trial in a judicial system that respects the rights of the parties. It should be guaranteed in a state's constitution and basic laws [1]. The legitimacy of judicial power through legislation is essential to ensure the legal independence of judicial institutions allowing them to carry out their functions without undue interference from government or other state institutions.

Independence of judicial power requires individual judicial qualities such as integrity, legal ability (with appropriate training and qualifications) so that the background of a judge is beyond reproach. Selecting competent judges is directly related to the recruitment process which should be transparent and free from 'cronyism'. The independence of the judge is maintained by

Manuscript received September 5, 2014; revised October 14, 2014. This work was supported in part by the Indonesian Directorate General of Higher Education under Competitive Research Grant (Hibah Kompetensi) 2014.

Yustina Trihoni Nalesti Dewi is with the Faculty of Law and Communication of Soegijapranata Catholic University, Semarang, Indonesia (e-mail: trihoni@unika.ac.id).

W. Riawan Tjandra is with the Law Faculty of Atma Jaya Yogyakarta University (e-mail: willyriawan@yahoo.com).

Grant R. Niemann is with Flinders Law School, Flinders University, Adelaide, Australia (e-mail: grant.niemann@flinders.edu.au). the judge performing his/her functions as part of the system of justice on behalf of the public and not for personal gain or advancement. The principle of Ex Aequo Et Bono gives freedom to judge not to be bound to the laws which he considers to be fair [2]. Any attempts to reduce the independence of the judge in performing his/her judicial functions including political influence should not be tolerated.

\section{JUDICIAL POWER IN INDONESIAN CONSTITUTIONAL SYSTEM AFTER THE AMENDMENT OF THE CONSTITUTION}

The amendments to the 1945 Constitution of the Republic of Indonesia resulted in fundamental changes being made to the structure, position and function of all state institutions (including the judiciary): the Presidency, the People's Consultative Assembly (MPR), The People's Representative Council (DPR and DPD), The Audit Board (BPK), the Judicial Commission, the Supreme Court and the Constitutional Court. The essence of constitutionalism is the division of power and to share power. Constitutionalism provides an effective system to limit government's actions [3].

These amendments were designed to influence and foster the growth of new values including democratic freedoms, people's sovereignty, protection of human rights, 'checks and balances', transparency, participation, accountability, and the rule of law.

These new values were intended to have wide raging implications for the Indonesian constitutional structure. Democratic values at the heart of the constitutional structure have been influential on things, such as the relationship between the state and the people, the inter-state institution relationships and the state's ability to build governance aimed at satisfying the will of the people. People's sovereignty has had the effect of shifting the mode of government away from executive control to parliamentary control with the Parliament being more directly involved in the in the selection process of public officials including Supreme Court and the Constitutional Court judges. The value placed on human rights protection was significantly enhanced with the enactment of Article 28 A - J of the 1945 Constitution which explicitly guaranteed human rights protections, something which was in stark contract to that which pertained before the 1945 Constitutional amendments.

The recognition of values such as transparency, participation and accountability as essential for good governance have led to the emergence of a constitutional structure which respects the need to foster and develop transparency, participation and accountability as 
fundamental tenets of a modern democratic state. The value of the rule of law has had a significant influence on the emergence and implementation of the rule of law theory in the constitutional system. The emphasis of the rule of law theory in the Constitutional arrangement has put the principle of observance of the law as a starting point for the constitutional system. The observance of the rule of law after the 1945 amendments has also given much weight to the notion of people's sovereignty in the constitutional structure.

The functional independence of the Supreme Court and Constitutional Court, as guaranteed in the constitution is another important facit strengthening the effect of the rule of law in the post amendment constitution. Article 24 paragraphs (1) of the 1945 Constitution of the Republic of Indonesia underscore the need for judicial independence in the ability of the courts to effectively carry out their judicial function of enforcing the law and dispensing justice. In other words the independence of judicial power is a guarantee to ensure the courts will enforce the law in a just and regular manner. This means, at least, three things; first, the independence of judicial power is a conditio sine qua non for the enforcement of law and justice; second, the independence of the judicial institution in performing it's judicial functions only has meaning if its performed in these circumstances; third, law enforcement cannot be separated from justice and it can only be realized if judicial power is exercised in an independent and unbiased manner.

Article 24 paragraphs 2 of the 1945 Constitution states that judicial power carried out by the Supreme Court applies to the lower courts, including general courts religious courts, military courts, and administrative courts, which all enjoy these constitutional guarantees for their functions in accordance with their jurisdictional competence. The affirmation of these constitutional guarantees in these four subordinate ensures that the independence of judicial power shall include the independence in their institutions position, the independence in implementation of judicial functions and the independence for the functionaries of judiciary (judges) in carrying out their professional responsibilities. The independence of judicial power as guaranteed in the constitution has the capacity to change the paradigm of dualism in the building of judicial power in the post 1945 Constitution amendment era [4].

\section{DYNAMIC INTERACTION AMONG THE ADMINISTRATORS OF STATE POWER AND THE EFFECT ON THE INDEPENDENCE OF JUDICIAL POWER}

The constitutional structure for the exercise of state power in the Republic of Indonesia after the amendment in regulating the system based on these principles of checks and balances, democracy, people's sovereignty, good governance and transparency along with protection guarantee of human rights should be a sufficient structural and systemic prerequisite for the existence of the independence of judicial power. However, a study of the constitutional system is inadequate if it is not implemented until the examination to the derivations in the system of legislation through legislative function as well as constitutional practices as reflected in the dynamic interaction among state institutions in state administration politics. The dynamic interaction among state institutions is an indicator that determines if the reality of the independence of judicial power as well as the quality of legislation product derived from the constitution has been realized.

Dynamic interaction among state institutions in the constitutional practices is a "real constitution" that can strengthen the principles contained in the texts of the constitution or even derogates those values in practice. Political influence in the operation of checks and balances between the legislative and the executive fails to internalize the basic values that have been the basis for the formulation of the constitutional provisions, and it can be a factor that can disrupt judicial power, directly or indirectly.

\section{THE OBSTRUCTIONS TO THE EFFECTIVENESS OF HUMAN RIGHT COURT}

The Human Right Court is a relatively new judicial institution having been established as a result of the enactment of Act No. 26, 2000 on Human Right Court. The establishment of the Human Rights Court was designed to foster the promotion and protection of human rights in Indonesia. The creation of the Court should in theory provide an opportunity for the court to settle human rights violations that have occurred in the past and it contribute to the reform of legal system in Indonesia. The Court should also be able to test the extent to which the Indonesian government is genuinely committed to the protection and promotion human rights. Further the Court could also contribute to enhancing the credibility and judicial effectiveness of the Indonesian judicial system in general. This would in turn contribute to the esteem to which the Court (and the judicial system generally) is held in the wider public community. Conversely the failure to carry out its judicial processes including the holding of public trials which reveal the truth of facts surrounding human rights abuses closes off any opportunity to improve the image of government, especially in law enforcement and the protection of human rights [5].

Unfortunately the provision of a fair trial is still not ensured before the Human Rights Court in Indonesia, despite fair trial guarantee being enshrined in the 1945 Constitution. What is before the law and according to law in fact is not in accordance with before the court and according to the court [6]. In practice the Human Rights Court, often falls short of providing litigants and victims alike with fair and just outcomes in cases before the Court. These cases often expose fundamental flaws in the trial processes, they are not performed properly and as a consequence do not provide justice for the victims.

One fundamental weakness is in the establishment of the Ad Hoc Human Rights Court. For permanent Human Rights Court, the establishment legitimacy is clear based on Act no. 26, 2000, against all the serious human right violations occurred after enactment of the Law. Nevertheless, the Ad Hoc Human Right Court which is to try serious human right violations before the application of the Human Right Court Law, the establishment seems to be quite controversial. The legitimacy of the Ad Hoc Human Right court is based on Article 43 of Act no. 26, 2000. Paragraph (1) states that gross 
violations of human rights occurring prior to the coming into force of this Act shall be heard and ruled on by an ad hoc Human Rights Court. Paragraph (2) states that an ad hoc human rights court as referred to in clause (1) shall be formed on the recommendation of the House of Representatives of the Republic of Indonesia for particular incidents upon the issue of a presidential decree. The People's Representative Council (DPR) as a political institution has the control whether to establish the Ad Hoc Human Rights Court or not, thus it is implicitly the same as giving authority to The People's Representative Council (DPR) to consider serious human rights violations in political context.

The other weakness is the strong influence of the New Order administration system that characterizes the attitude of law enforcement officials, including judges who are not independent because they see themselves as being beholden to the political institutions that appointed them. These Judges often have a culture of loyalty to government and government policy and not to the law and the provision independent fearless adjudication [7]. The process of judicial recruitment consists of career judges and non-career judges and does not take place in a transparent way. The requirements for suitable legal qualifications of the judges are so vague and unclear that the public cannot be confident that the best lawyers are being selected as judges of the Human Right Court. In addition, the selection process is inadequate because it is not transparent so as to ensure that 'fit and proper' persons are selected by the appointing authorities.

The 5 judges of the Human Right Court consist of two career judges and three ad hoc judges (the career judges generally meet the selection requirements). But the Ad Hoc Judges in District Courts and Appellate Courts are appointed and dismissed by the president as the head of state upon the recommendation of the Chief of the Supreme Court. In addition, the ad hoc judges of the Supreme Court are appointed by the President as head of state on the recommendation of The People's Representative Council (DPR). In order to guarantee the independence of the judges, the appointed judges should be determined by an independent and non-political body.

In addition to the appointment of a judge should be open to the public, the selection of judges who will handle a case should also be open so that the parties with the interest in the court cannot "manage" the composition of the judges. Public participation with a great attention to law enforcement is a control mechanism over the trial process, especially in cases which are sensitive to the public's sense of justice especially in cases involving serious violations of human rights. Community participation and or control needs to exist from the beginning to the end of the trial process and the public need to be able to examine whether the legal reasoning used in the overall process of law, both from the inquiry, investigation, prosecution, examination and decision of court are in accordance with sound legal principle With such public participation, judges and all parties involved in a judicial process are then made accountable which will in turn improve the integrity, credibility, and professionalism of the legal participants.

The selection of a judge must be based on objective criteria so as to ensure that the appointments are based on qualifications and ability and not on political favoritism. The lack of judicial competence has been a real problem which has weakens the independence and effectiveness of the Human Right Court. The report of the UN Expert Commission on the Ad Hoc Human Rights Court for East Timor also noted the lack of training on international standards and practices relevant to the prosecution of serious crimes against humanity.

The quality and competence of judges was a particular problem in the case of the Human Right Court established for East Timor. It was found that these Judges often lacked an understanding of the fundamental concepts involved with the investigation and prosecutions of crimes against humanity based on the command responsibility model. This lack of understanding proved fatal to the trials conducted before the Court. Decisions of the Court demonstrated that the judges failed to understand the requirements of proving essential such as 'widespread or systematic' or how command responsibility could be proved. This lack of understanding also proved to be the cases that went before the appellate Court. The judges paid little attention to international doctrines and made mistakes in using the doctrines about superior and subordinate, the elements of knowledge, effective control, and other elements [8]. Meanwhile, in the Abepura Court's Decision, the judges failed to understand and follow the development of international penal law, humanitarian law, and other relevant international legal principles. The recruitment process applied to the appointment of these judges did not include the need to ensure that they were knowledgeable of and competent in international law. Consequently the trials shows that a number of judges did not have an international criminal law background or the relevant knowledge which in turn cause them to make mistakes in understanding the instruments of international human right law [9].

\section{CONCLUSION}

1) The Amendment to Article 24 of the 1945 Constitution has made Indonesian Judicial Authority gains legal legitimacy to run the full independence that focuses on the independence of judges who are not influenced by other powers out of the structure of judicial power.

2) Constitutional reform becomes a driving force strengthening the independence of judicial power in which the Supreme Court as the highest judicial institution begins to break away from the Government control. Through this reform, the entire judicial institution and quasi-judicial institutions is under the hierarchy of the Supreme Court having the authority over the administration, resources, and technical from the institutions under their hierarchy.

3) Competent, independent, and impartial courts will also depend also on the judges who have integrity, ability with appropriate training and higher qualifications in law enforcement. It is influenced by several factors; the guarantee of judicial power independence by the constitution, the competence and capacity of judges in carrying out judicial functions and the quality of court 
decisions in accordance with the principles of quality substantive and formal law viewed from the point of the making of legal norms.

4) There are still weaknesses in the judicial system of human rights with the position located between the existence of the guarantees of judicial power independence set in textual- explicit in the constitution (normative-theoretical context) and the needs for the practice of human right courts through the decisions that protect human rights substantively (factual-applicative context) requires a re-conceptualization of the position and function of the human right court based on the philosophy on the independence of judicial power.

\section{REFERENCES}

[1] Basic Principles on the Independence of the Judiciary. (1985). [Online] Available:

http://www.ohchr.org/EN/ProfessionalInterest/Pages/IndependenceJu diciary.aspx

[2] J. Djohansyah, Reformasi Mahkamah Agung - Menuju Independensi Kekuasaan Kehakiman, Kesaint Blanc, Bekasi, 2008, p. 8.

[3] D. Indrayana, Amandemen UUD 1945 - Antara Mitos dan Pembongkaran, Mizan, 2007, p. 123

[4] S. Pompe, Runtuhnya Institusi Mahkamah Agung, The Institute of Studying and Avocation for Judicial Independence, 2012, pp. 113.

[5] Monitoring Pengadilan HAM Timor-Timur. [Online]. Available: http://www.elsam.or.id/pdf/monham/timtim/Prog-Report\%2010.pdf.

[6] Soetandyo Wignjosoebroto at Uli Parulian Sihombing. [Online]. Available: http://mitrahukum.org/file/buku/Peradilan\%20adil.pdf

[7] J. F. Junge, Kesempatan yang Hilang - Janji yang Tak Terpenuhi: Pengadilan HAM Ad Hoc untuk Kasus Tanjung Priok 1984, KontraS/ Watch Indonesia, Jakarta, 2008, p. 33.

[8] D. Cohen, F. Agus, and W. Wulandari, Pengadilan Setengah Hati: Eksaminasi Publik atas Putusan Pengadilan HAM Kasus Timor Timur, ELSAM, Jakarta, 2008, pp. 126 - 127.

[9] D. W. Christianti, I. Kasim, and T. N. Dewi, Pengadilan Pura-pura: Eksaminasi Publik atas Putusan Pengadilan HAM Kasus Abepura, ELSAM, Jakarta, 2008, p. 106.

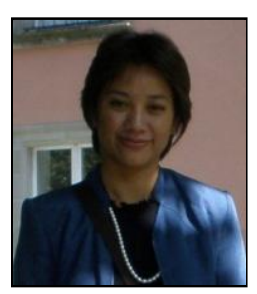

Yustina Trihoni Nalesti Dewi was born in Yogyakarta, Indonesia in 1969. She graduated from Faculty of Law of Gajah Mada University, Yogyakarta, Indonesia. she is majored in international human rights and humanitarian law.

She works at Faculty of Law and Communication of Soegijapranata Catholic University, Semarang, Indonesia. She wrote books and one of them is War Crime in International and National Law Perspectives in 2012 and she got published by Rajawali Grasindo. She was invited as a visiting scholar at Flinders Law School, Adelaide, Australia (2010 and 2013) and as a guest researcher at Norwegian Center for Human Rights, Oslo University, Norway in 2009. She was also actively invited as a speaker and resource person on human rights and humanitarian law issues in the workshops, seminars, and courses for the Indonesian lecturers and public officials.

W. Riawan Tjandra was born in Madiun, Indonesia on May 16, 1969. He graduated from Faculty of Law of Brawijaya University, Malang, Indonesia he received his undergraduate, postgraduate, doctorate programme from Gajah Mada University, Yogyakarta, Indonesia in 1993, 2003, 2009. he is majored in administrative law.

He works at Faculty of Law of Atma Jaya University Yogyakarta, Indonesia. He wrote some books on administrative law matters. He was invited as visiting scholar at Flinders Law School in 2013. He was also actively invited as a speaker and resource person on administrative law issues for the public officials.

Grant. R Niemann was graduated from Sydney University (LLB) Adelaide University (LLM, Graduate Diploma of Public Law), Flinders University (Graduate Certificate of Tertiary Education and Doctor of Philosophy).

He works as a senior lecturer at Flinders Law School, Adelaide, Australia and a lawyer with extensive experience in practice. He was formerly chief Lawyer of Northern Land Council Darwin, the assistant director of Legal Services, Australian Government Solicitors Office Adelaide, then as the deputy director of the Commonwealth Director of Public Prosecutions Office Adelaide, then appointed first senior trail attorney of the International Criminal Tribunal for the former Yugoslavia before taking up appointment as a legal academic at Flinders University School of Law. He got Distinguished Service Award for work in the area of international humanitarian law, Australian Red Cross 